\title{
Cumhuriyet'in İlk Yıllarında Tarih Öğretimi
}

\author{
Prof. Dr. Mesut ÇAPA*
}

\section{ÖZET}

Cumhuriyetin ilk yıllarında Atatürk ve arkadaşlart, yeni ve modern bir devlet yaratmak için eğitimin çok önemli olduğunun farkına vardılar. Bu çerçevede, e ğitim alanında yapılan ilk reformlar arasında tarih ögretimine özel bir önem verildi ve ilköğretim tarih müfredat programı 1924 ve 1926 yıllarında iki kez değiştirildi. 1930'larda tarih öğretimiyle ilgili önemli bir karar alındı ve Türk Tarih Tezi yürürlüğe konuldu. Bu çerçevede, ilk ve ortaögretime yönelik olarak yeni tarih ders kitapları yazıldı ve yüksek öğretimde İnkılâp Tarihi dersleri okutulmaya başlandı. Bu makalenin amacl, Atatürk dönemi tarih öğretimini ders kitaplart, müfredat programları ve öğretim yöntemleri açısından incelemektir. Bu çerçevede, Atatürk dönemi tarih ders kitapları ve müfredat programları araştırılmıştır. Elde edilen verilerin ışı̆̆ı altında, Atatürk döneminde yeni ve modern bir devlet yaratmak için, tarihin önem verilen disiplinlerden biri olduğu ve bu alanda önemli çalışmaların yapıldı ğı görülmektedir.

Anahtar Kelimeler: Tarih Öğretimi, Tarih Müfredatı, Ders Kitapları, Türk Tarih Tezi, Millı Tarih, Cumhuriyetin Illk Yılları

The Teaching of History in The First Years of Turkish Republic

\section{ABSTRACT}

During the establishment of Turkish Republic, Atatürk and his associates recognised that education is one of the important components in order to create a new and modern state. Among the first initiatives of education, the teaching of history was given great attention and in 1924 and 1926 history curriculum in the primary level had been changed twice. An important decision concerning the teaching of history was taken in 1932 and the Turkish History Thesis came into force. After the Turkish History Thesis, new history textbooks were written for

• Karadeniz Teknik Üniversitesi Fatih Eğitim Fakültesi, Orta Öğretim Sosyal Alanlar Eğitim Bölümü Başkanı 
primary and secondary levels. Furthermore, higher education students were also required to learn Turkish Revolution History. The purpose of this paper is to examine the developments in the teaching of history in the Atatürk's era in terms of history textbook, history curriculum and teaching methods. With this in mind, history textbooks and history curriculum used in the Atatürk's era are investigated. In the light of the data, it can be said that the teaching was seen a key subject in order to create a new and modern state.

Key Words: The Teaching of History, History Curriculum, History Textbooks, The Turkish History Thesis, National History, First Years of The Turkish Republic

\section{Giriş}

Cumhuriyet'in kuruluşuyla birlikte eğitimin her alanında olduğu gibi, Tarih eğitim ve öğretiminde de önemli değişiklikler yapılmıştır. Atatürk dönemindeki gelişmeleri kapsayan bu bildiride, öncelikle ilk ve ortaöğretimde tarih müfredatı, tarih ders kitapları ve öğretim metotlarındaki değişme ve arayışlar ve muhtelif eleştirilere yer verilmektedir. Cumhuriyet'in ilk yıllarında yayınlanan ders kitapları, müfredat programları ve eğitimle ilgili diğer yayınlar bildirinin temel kaynaklarını oluşturmaktadır.

Cumhuriyet'in ilk yıllarındaki uygulamaları 1930 öncesi ve sonrası diye ikiye ayırmak mümkündür. 1930'lardan önce ilkokul müfredatı 1924 ve 1926 yıllarında değişikliğe uğramıştır. Bu tarihlerde Mehmet Fuat (Köprülü), İhsan Şerif (Saru), Ahmet Halit (Yaşaroğlu) v.d. tarafından ilkokul tarih kitapları yazılmıştır. Aynı tarihlerde lise ve ortaokul ders programlarında da değişiklikler yapılmış; buralarda Ahmet Refik (Altınay) ve Ali Reşat Beylerin kitapları okutulmuştur. 1926 yılından itibaren ders kitaplarının hazırlanması ve basımı Milli Talim ve Terbiye Dairesi'nin sorumluluğuna bırakılmıştır.

1930 yılına gelindiğinde, Türk Tarih Tezi'nin uygulamaya konulmasıyla önce liselerde ve ardından ortaokul ve ilköğretimde yeni hazırlanan tarih kitapları okutulmaya başlanmıştır. Bildiride, bu yıllarda daha da önem kazanan ve yükseköğretimde verilmeye başlanan İnkılâp Tarihi dersleri de söz konusu edilmektedir.

\section{Müfredatta Değişiklikler ve Tarih Müfredatı}

1930'dan önce ilk değişiklik müfredat programlarında yapıldı. 1924'te ilk, orta ve lise ders programları bir komisyon tarafından yeniden düzenledi. Daha sonra buna bağlı olarak yeni ders kitapları yazıldı.

İlkokul müfredat programları bir kaç yıl içinde iki defa değiştirildi. 1924 programına göre tarih dersi, ilkokulların üçüncü sınıflarında "daha ziyade bir kıraat ve musahebe" şeklinde verilirken, dördüncü ve beşinci 
sinıflarda Genel Tarih ve Türk Tarihi okutulmaktaydı. 1926'da yapılan değişiklikle, yeni eğitim esaslarının gerektirdiği toplu eğitim metodu uygulamaya konularak ilk üç sınıfta Hayat Bilgisi dersine, önceki gibi, yine dördüncü ve beşinci sınıflarda asıl tarih derslerine yer verildi ${ }^{1}$.

1927-1928 öğretim yılında bütün ilkokullarda uygulanan son programda tarih dersinin hedefi, "Çocuklara Türk milletinin mazisi hakkında malûmat verip onlarda millî şuur uyandırmak; bugünkü medeniyetin uzun bir mazinin mahsulü olduğunu anlatmak; büyük şahısların hayat ve hareketleri tasvir edilerek çocuklara imtisale şayan numuneler göstermek." ${ }^{2}$ şeklinde belirlenmişti. Bu programda "Millî Tarih" anlayışına önem verilerek Türk tarihi, başlangıcından Cumhuriyet'in kuruluşuna kadar bir bütünlük içinde ele alınıyordu. Programda İslam tarihine hiç yer verilmediği gibi, Osmanlı tarihi de yeni bir yaklaşımla hanedana övgü olmaktan çıkarılmışı.

Nitekim, dördüncü sınıf programının sadece giriş kısmında, insanlığın ilk zamanları ve tarih öncesi yaşayışlarıyla eski büyük medeniyetlerden bahsediliyordu. Diğer yandan, "Eski Türk yurdu ve Orta Asya hakkında kısa coğrafî̀ malumat" ile başlayan "Millî Tarih", Osmanlı Devletinin kuruluşundan sonra "muhtasar bir surette, Cumhuriyet devrine kadar" getiriliyordu. Beşinci sınıfta, Genel Tarih ve Ortaçağ'da Doğu ve Batının karşılaştırılmasından sonra Yeni ve Yakınçağlarda Avrupa ve Türk Tarihine yer verilmekteydi. Batıda Reform ve Rönesans hareketiyle başlayan gelişmeler çerçevesinde Avrupa'da mutlakıyetçi devletler, İngiltere'de Meşrutiyet, Fransız İnkılâbı, Sanayi İnkılabı gibi konulara değiniliyordu. İstanbul'un fethinden Cumhuriyet'e kadar getirilen Türk tarihi çerçevesinde siyasî olayların yanı sıra Osmanlı Medeniyeti, Fransız İhtilali'nin etkisi, Türklerde yenilik hareketleri gibi konulara da yer veriliyordu. Ayrıca, "bugünkü dünyaya bir nazar" ${ }^{3}$ konusuyla öğrencilerin çağdaş dünyayı tanımaları hedeflenmekteydi.

1930 yılı öncesi ortaokul ve lise müfredatında da bazı değişiklikler yapıldı̆̆ 1 görülmektedir. Cumhuriyet dönemine intikal eden "Mekteb-i Sultani" müfredat programında, Sultanilerin birinci devresinde dördüncü sinıftan sekizinci sinıfa kadar haftada on saat tarih dersi yer alıyordu. Dördüncü sınıfta eski usul değiştirilmeyerek "Tarih-i Enbiya, Tarih-i İslam" okutulmaktaydı. Beşinci sınıftaki Osmanlı tarihi, "Türklerin menşeleri"nden başlayıp Osmanlı Devletinin kuruluşuna kadar olan dönemi kapsıyordu. Sultanilerin altıncı, yedinci ve sekizinci sınıflarında ise, Eskiçağ'dan Yakınçağ'a kadar kronolojik bir sıra takip edilerek Birinci Meşrutiyet'e kadar getirilen Osmanlı tarihi Avrupa tarihiyle birlikte verilmekteydi.

'Mete Tunçay, "İlk ve Orta Öğretimde Tarih”, Türkiye'de Tarih Eğitimi, Felsefe Kurumu Seminerleri: 3, Ankara 1975, s.277-278; Ekrem Üçyiğit, "Illk ve Orta Öğrenimde Tarih”, a.g.e., s.269-275; Cumhuriyet Halk Partisi On Beşinci Yıl Kitabı, (t.y), s.17.

2 Illk Mekteplerin Müfredat Programı, İkinci tab', Devlet Matbaası, İstanbul 1927, s.71.

${ }^{3}$ A.g.e., s.73-74. 
Sultanilerin ikinci devresini oluşturan dokuzuncu, onuncu ve onbirinci sınıflarının Fen şubesinde 8, Edebiyat şubesinde ise 12 saat tarih dersi konulmuştu. Programda Osmanlı tarihinin yanı sıra Avrupa tarihine de yer verilmekteydi. Bu konuların özellikle son dönemlerde birlikte ele alındığı görülmektedir. Nitekim, on birinci yılda okutulacak olan konular, "İngiltere ile İttifak, Suavi Vakası, Berlin Muahedesi"yle son buluyordu. Edebiyat şubesi programında, Fen şubesinden farklı olarak onuncu ve onbirinci sınıfta ikişer saat fazla tarih dersi yer alıyordu. Bu sebeple, Edebiyat şubesinin onuncu sınıfında İlkçă̆ ve Ortaçağ'da Romalılar, Slavlar, Türkler ve İranlılar; onbirinci sınıfta ise, İslam ve Türk Medeniyet tarihi hakkında bilgiler veriliyordu ${ }^{4}$.

Sultaniler Cumhuriyete eski programlarıla girmekle birlikte, TemmuzAğustos 1923'te toplanan Birinci Heyet-i İlmiye'de alınan karardan sonra lise olarak adlandırılmışlardır. Asıl değişiklik, 1924'te toplanan İkinci Heyet-i İlmiye'de gerçekleştirilmiştir. Liseler üçer sınıflık birinci ve ikinci devrelere ayrılarak, lise ve ortaokul müfredat programları yeniden düzenlenmiştir. Buna göre, liselerin birinci devresi ile müstakil ortaokullar üç yıllık bir bütün sayılıyordu. Liselerin son sınıfı edebiyat ve fen olmak üzere iki şubeye ayriliyordus.

1924 yılında yapılan yeni düzenlemelere göre, liselerin ikinci devresinde her sınıfta ikișer saat olmak üzere, üç yılda toplam altı saat tarih okutulmaktaydı. Konular, dördüncü sınıftan altıncı sınıfa kadar kronolojik bir sıra takip etmekteydi. İlkçağ'dan başlayan dördüncü sınıf programı, eski Doğu milletleri (Misırlılar, Keldani ve Asuriler, Fenikeliler, Hititler, İranlılar, İbraniler) ve medeniyetlerinden başlıyordu. Yunanlılar (Adalar Denizi Medeniyeti) ve Romalılara etraflıca yer verildikten sonra, Ortaçağ'da Barbarlardan, Avrupa devletleri ve medeniyetlerinden bahsedilirken 13-15. yüzyıllarda "Avrupa ile münesabatımız nokta-i nazarından" Türk tarihine yer veriliyordu. Beşinci sınıf programı Yeniçağ'da Avrupa ve Osmanlı tarihi ile Fransız İhtilali'ni kapsıyordu. Altıncı sınıfta Yakınçağ (Asr-1 Hazır) Tarihi çerçevesinde Viyana Kongresi'nden başlayarak Avrupa'daki gelişmeler, "Ondokuzuncu Yüzyılda Osmanlı İmparatorluğu. Bugünkü Türk alemine umumi bir nazar", "Medeniyet-i hazırânın evsaf-1 umumiyesi" gibi konular yer almaktaydı. Ayrıca, son sınıfta yalnız Edebiyat şubesinde haftada iki saat Türk Medeniyet tarihi dersi okutulacaktı ${ }^{6}$.

Anlaşılacağı üzere, 1924 programına göre liselerde Avrupa merkezli bir tarih öğretimi söz konusuydu. Programda, Türk tarihinden ziyade, Genel tarih ve Avrupa tarihine öncelik verilmekteydi. Bu programın öncekinden en önemli farkı İslam tarih ve medeniyetine yer verilmemiş olmasıydı.

${ }^{4}$ Mekatib-i Sultaniye Müfredat Programı, Matbaa-i Amire, İstanbul 1338, s. 5-7, 54-55, 58-68, 188, 193-201, 206-213

${ }^{5}$ Türkiye Cumhuriyeti Maarifi, 1923-1943, Maarif Matbaası, Ankara 1944, s.37.

${ }^{6}$ Liselerin İkinci Devre Müfredat Programı, Matbaa-i Amire, İstanbul 1340, s.8-19. 
Ortaokul ve liselerde uygulanan bu tarih programı, 1927 yilında baz1 tadilata uğramış ise de; asıl değişiklik ilk, orta ve liseleri kapsayacak şekilde Türk Tarih Tezine göre 1930'dan sonra yapılmıştır. Öğretimde müfredatın ağırlığının sakıncalarını ortadan kaldırmak amacıyla, 1935'te üniversite ve lise öğretmenlerinden oluşan komisyonlar tarafından her ders için birer kılavuz hazırlanarak programlar bir dereceye kadar hafifletilmiştir ${ }^{7}$.

1936 'da ortaokul birinci ve ikinci sınıflarda ikişer, üçüncü sınıfta üç saat olmak üzere haftada yedi saat tarih dersi okutuluyordu. Liselerin ikinci devresinde de aynı oranda tarih dersi bulunmakla birlikte, daha önce lise üçüncü sınıfta Edebiyat şubelerinde fazladan verilen tarih dersi kaldırılmıştı. İlköğretmen okullarında birinci, ikinci ve üçüncü sınıflarda ikişer saat; Ankara Musiki Öğretmenokulunda da yine birinci, ikinci, üçüncü ve dördüncü sınıflarda ikişer saatten toplam sekiz saat tarih dersi yer alıyordu.

İlköğretmen okullarındaki program önemli ölçüde Türk Tarih Tezini yansıtmaktaydı. Birinci sınıf müfredatında bunu açıkça görmek mümkündür. İnsanlık tarihine girişle başlayan ilk bölümde evren (kainat), tabiat, tarih, 1rk, dil ve bu çerçevede Türk ırkı ve Türk dili kavramlarına yer verilmekteydi. "Büyük Türk Tarihi ve Medeniyetine Umumi Bir Bakıș" başlığı altında eski Türk tarihi ve kültürünün yanı sıra, eski Anadolu ve Önasya medeniyetlerinden bahsediliyordu. Bu çerçevede, "Türklerin anayurdu, umumi muhaceretler ve medeniyetler, Önasya, Sümer, Elam, Eti, Mısır, Ege Havzası, Türklerde madencilik, Eski Türk şehirleri, Ortaasya'da medeniyet merkezleri, Milattan evvel XIII. Asırdan sonra kurulan Türk devletleri, Türklerde yazı, Eski Türklerin hukukuna umumi bakış, Eski Türklerde din vb." konulara değiniliyordu. Daha sonra ise, "Çin, Anayurtta en eski devletler, İskit İmparatorluğu, Hint, Kalde, Elam ve Asur, Misır, Anadolu, Etiler İmparatorluğu, Frikya, Lidya, Fenikeliler, İbraniler, İran, Ege Havzası, Eski İtalya ve Etrüksler"e yer verilmekteydi.

Ortaçağ tarihini içeren ikinci sınıf programında da Türk tarihiyle ilgili konular (Alanlar, Avrupa Hun İmparatorluğu, Akhunlar, Avarlar, Göktürkler, Türkeş Devleti, Karluklar, Uygurlar, İlk Müslüman Türk devletleri vb.) ağırlıktaydı. Ayrıca bu konularla ilgileri ölçüsünde "Altıncı Asırda Doğu Roma İmparatorluğu, Mukaddes Roma Germen İmparatorluğunun Kuruluşu, Hıristiyan derebeylikleri, Haçlı seferleri" gibi konulara da yer veriliyordu. Üçüncü sınıfta ise, "Yeni ve Yakın zamanlar tarihi" çerçevesinde kuruluşundan itibaren Osmanlı ve Avrupa tarihi ele alıniyordu ${ }^{8}$.

1930'lardan sonra ilköğretimden yükseköğretime kadar her öğretim kademesinde Cumhuriyet ve İnkılâp tarihi öğretimine önem verildiği görülmektedir. Nitekim ilköğretmen okullarında, yukarıda açıkladığımız

\footnotetext{
${ }^{7}$ Türkiye Cumhuriyeti Maarifi, s.37-38.

${ }^{8}$ Türkiye Okulları Kılavuzu, Devlet Basımevi, İstanbul 1936, s.3,9,20,23.
} 
programa ek olarak, onbeş günde bir saat Türkiye Cumhuriyeti ve İnkılâp Tarihi okutuluyordu.

Bu tarihlerde yüksek öğretimde başlatılan İnkılâp Tarihi öğretiminden kısaca bahsetmek gerekecektir. Üniversite reformundan bir yıl sonra, 1934 'ten itibaren İstanbul ve Ankara'da fakülte ve yüksek okullarda İnkılâp Tarihi ders ve konferansları verilmeye başlandı. Amaç, Avrupa'da yayılmaya başlayan totaliter rejimlere karşı gençliği aydınlatmak ve onların Cumhuriyet ideallerine ve inkılâplara bağlılıklarını sağlamaktı․ İlk defa İstanbul Üniversitesi'nde başlatılan çalışmalarla ilgili bir haberde, "Maarif Vekaleti, inkılâp fikriyatının bütün tahsil derecelerinde temel olmasına büyük ehemmiyet atfettiğinden yeni ve mühim bir karar daha vermiştir. Bu karara göre Üniversitede bir İnkılâp Enstitüsü tesis edilerek Türk inkılâbının malî, ictimaî, hukukî ve iktisadî esasları ve istikametleri ders halinde okutulacaktır." ${ }^{10}$ denilmekteydi.

1934 yılında İstanbul Üniversitesi'nde İnkılâp Enstitüsü kuruldu. Atatürk'ün güvendiği ve inkılâbın öncülüğünü üstlenmiş olan siyasetçi ve devlet adamları (Yusuf Hikmet Bayur, Mahmud Esad Bozkurt, Yusuf Kemal Tengirşek, Recep Peker) tarafından İnkılâp Tarihi dersleri verilmeye başlandı. 1934-1935 öğretim yılından itibaren 1942 yılına kadar İstanbul Üniversitesi ve Ankara Hukuk Fakültesi ve yüksek okullarda İnkılâp Tarihi dersleri veren Recep Peker ilk dört dersinde sırasıyla İnkılâbın Manası, Hürriyet İnkılâbı, Sınıf İnkılâbının Reaksiyonları konularını ele almıştır ${ }^{11}$.

Ankara'da ilk İnkılâp Tarihi dersi Başbakan İsmet İnönü tarafından, Ankara'daki yüksekokulların son sınıf öğrencilerine 20 Mart 1934'te İnkılâp Tarihi Kürsüsünde verildi. Maarif Vekili Hikmet Bayur tarafından Halkevi salonunda verilen ikinci derse ise Ankara'nın tanınmış simaları, milletvekilleri ve Hukuk Mektebi öğrencileri katıldd ${ }^{12}$. Müteakib yıllarda bu dersler daha düzenli bir programa bağlandı.

\section{Tarih Ders Kitaplart}

Cumhuriyetin ilk yıllarında müfredatlara bağlı olarak ders kitaplarında önemli değişikler yapılmıştır. Özellikle ilkokul ders kitapları millî tarih anlayışı çerçevesinde yazılmaya başlanmıştır. Bununla birlikte, lise kitaplarının eski metod ve anlayıştan arındırılması zamanla mümkün olabilmiştir.

${ }^{9}$ Hilmi Ziya Ülken, "Cumhuriyetimiz, Atatürk İnkılâpları, Türk Milliyetçiliği, Millî Birlik ve Beraberlik”, 50. Yıl Konferansları, Millî Eğitim Basımevi, Ankara 1974, s. 194.

10 “ Üniversitede Bir İnkılâp Enstitüsü Açılacak”, Cumhuriyet, 21 Haziran 1933.

$"$ Fikirler, C.VI, Sayı: 133, s.2-4; Sayı:134, s.2-5; Sayı:135, s.2-5; Say1:137, s.2-5; Sayı:140, s.2-3; Sayı:141, s.2-3; Sayı:142, s.2-4.

12 "İsmet Paşamızın İnkılâp Dersi”, Serveti Fünun, 29 Mart 1934, No: 1962-277, s.276; “Ankara İnkılâp Kürsüsünde”, Serveti Fünun, 5 Nisan 1934, No: 1963-278, s.297. 
Osmanlı devletinin son döneminde tarih ders kitabı yazanların çoğu, bu çalışmalarını Cumhuriyet döneminde de sürdürmüşlerdir. 1930 yılı öncesinde ilkokullar için Mehmet Fuat (Köprülü), İhsan Şerif (Saru), Ahmet Refik (Altınay), Ahmet Halit (Yaşaroğlu) ve Emin Ali (Çavlı) gibi tarihçi ve öğretmenler tarih ders kitapları yazmışlardır. Bu kitapların isim ve muhteviyatına bakıldığında, ilkokullarda milli tarih öğretimine öncelik verildiği anlaşılmaktadır. Bu kitaplar "Millî Tarih", "Cumhuriyet Çocuklarına Tarih Dersleri", "Türk Çocuklarına Tarih Dersleri" ve "Bizim Tarih" gibi adlarla yayınlanmışlardı.

Mevcut tarih kitaplarının eğitimin hedefleri açısından yetersizliği Cumhuriyet öncesinde tartışılmaya başlanmıştı. Fuat Köprülü 1921 yılında yayınladığı "Millî Tarih"te bu konudaki görüşlerini şöyle dile getiriyordu:

"Elde mevcut tarih kitapları, çocuklara yanlış malumat vermekle beraber, aynı zamanda tarih tedrisatının başlıca hedeflerinden biri olan millî terbiye hususunda müfîd değil bilakis muzır bir mahiyettedirler: Binlerce yıllık bir hayat, şan ve şerefe malik olan muazzam Türk milletini dörtyüz çadır halkından mürekkeb bir göçebe halk gibi gösteren, milletimizin Anadolu'da ve Rumili'deki kadim tarihiyesini hiç düşünmeyen, Türk medeniyet-i kadimesini, Avrupa müelliflerini takliden, inkar eden, Moğolları Türklerden sayan, cihan tarihini Türk-İslam tarihi nokta-i nazarından tedkik edecek yerde Frenk kitaplarını aynen taklid eden, tab'ları ve resimleri itibariyle çok fena olan bu eserler, bir Türk çocuğunun eline yakışacak şeyler değildir. İşte Millî Tarih silsilesi, sırf bu noksanları izale ve millî terbiyenin en mühim bir rüknünü tesis maksadıyla vücûda getirilmiştir." ${ }^{13}$

Millî Mücadele döneminde yaygın olarak kabul gören millî tarih anlayışında, tarih öğretimi Tanzimat öncesi ve sonrası bakış açısından tamamen ayrılıyordu. Ders kitaplarında artık İslam öncesi Türk tarihiyle, İslam tarihi içinde Osmanlı öncesi Türk tarihine geniş yer verilecekti. Aynı zamanda, ilkokul ders kitapları ve müfredat programları genel tarih kültürünü kapsayacak şekilde genişletilecekti.

Fuat Köprülü'nün, 1924 müfredat programı çerçevesinde ilkokul dördüncü sınıflar için yazdığı kitabında Türk tarihiyle ilgili konular Türkler, Oğuz Türkleri, Osmanlı Devletinin Kuruluşu, Türk-İslam Medeniyeti gibi başlıklarla veriliyordu. Genel tarih konuları ise Mısırlılar, Finikeliler, Keldaniler-Asuriler, İranlılar, Hititler, İsrailoğulları, Yunanlılar, Romalılar, Ortaçağ, Arap Tarihi, İslam'da Cumhuriyet Devri, İslam'da Mutlakiyet Devri şeklinde kronolojik bir sıra takip etmekteydi ${ }^{14}$. Galatasaray Lisesi Türkçe öğretmeni Ahmet Halit (Yaşaroğlu)'in ilkokul beşinci sınıflar için yazdığı

\footnotetext{
${ }^{13}$ Köprülüzade Mehmed Fuad, Millî Tarih, Kanaat Kütüphane ve Matbaası, 1337, s.63.

${ }^{14}$ Köprülüzade Mehmed Fuad, Millî Tarih, Kanaat Kütüphanesi ve Matbaası, 1340.
} 
kitapta ise konular, Yeniçağ'dan başlayıp Osmanlı tarihine ağırlık verilerek Türkiye Cumhuriyeti'nin kuruluşuna kadar getirilmekteydi ${ }^{15}$.

1923-1926 yılları arasında ders kitaplarının hazırlanmasında Maarif Vekaleti'nin fazla etkili olmadığı anlaşılmaktadır. 22 Mart 1926'da Millî Talim ve Terbiye Dairesi'nin kurulması bu konuda önemli bir başlangıç oldu. Bu tarihte, " Mektep kitaplarının Maarif Vekaleti'nce tab'ı hakkındaki Kanun"la ders kitabı basımı Millî Talim ve Terbiye Dairesi'nin sorumluluğuna birakıldı ${ }^{16}$.

Bu gelişmelerden sonra Fuat Köprülü, son müfredata göre 1928 'de ilkokul beşinci sınıflar için daha kapsamlı bir Milli Tarih kitabı yayınladı. Milli Talim ve Terbiye Dairesi'nce onaylanan bu kitap, şekil ve muhteva itibarıyla yazarın daha önce aynı adla yayınladığı kitaplardan farklıydı. Burada ilk defa "Gazi'nin Gençliğe Hitabesi"ne yer verilmişti. İlkokul beşinci sınıf müfredatına uygun şekilde sıralanan konular bölüm sonlarında özetlenmekteydi. Yine her bölümün sonunda okuma parçaları (tarihi kıraatler)'na yer verilmekteydi. Sade bir üslupla kaleme alınan kitap, "Umumî tarihe bir bakış"la başlayıp "Yeryüzündeki Türkler" konusuyla sona ermekteydi. Türkiye Cumhuriyeti ve inkılapların önemle vurgulandı̆̆ kitapta, "Cumhuriyet'in iyilikleri"nden şöyle bahsedilmekteydi:

"Saltanat kaldırıldıktan sonra, Osmanlı ailesinden biri halife olarak intihab edilmişti. Halbuki, Müslümanlıkta, esasen halife diye bir şey yoktu. İslamda ilk halifeler, hakikatte, o zamanki İslam cumhuriyetinin reisleriydi. Binaenaleyh, İstanbul'da halife namıla Osmanlı ailesinden birisinin oturması ve Türkiye Cumhuriyeti dahilinde hilafet diye bir mevki bulunması, hem manasız hem de zararlıydı. Cumhuriyet idaresi bu manasızlığı ortadan kaldırdı; bütün Osmanlı ailesini hududdan dışarı çıkardı. Kurun-1 Vusta yadigarı olan medreseleri, şeri mahkemeleri kapattı; halkı soymaktan ve fena yollara sevketmekten başka hiçbir faydası olmayan tekyeleri ortadan kaldırdı. Medeniyet dünyasının her tarafında olduğu gibi din ve dünya işlerini ayırdı. Muhakemelerimizde Avrupa milletlerinin en iyi kanunlarını tatbik etmeğe, memleketin her tarafında demiryolları, şoseler, fabrikalar, limanlar, şirketler, bankalar yapılmağa, ilim ve maarif teşkilatımız süratle ilerlemeğe başladı. Hülasa, bugün bütün memleket, büyük Gazi'nin açdığı nurlu medeniyet yolunda, onun rehberliğiyle yürüyor." ${ }^{17}$

\footnotetext{
${ }^{15}$ Ahmed Halit, Bizim Tarih, Amedi Matbaası, İstanbul 1924.

16 "Mektep Kitaplarının Maarif Vekaletince Tab'ı Hakkındaki Kanun", Maarif Vekaleti Mecmuası, Sayı:7, Mayıs 1926, s.41-46.

${ }^{17}$ Köprülüzade Mehmed Fuad, Milli Tarih, Yeni tab', Amedi Matbaası, İstanbul 1928, s.162.
} 
İhsan Şerif (Saru)'in ilkokul beşinci sınıf için yazdığı Cumhuriyet Çocuklarına Tarih Dersleri ${ }^{18}$, Talim ve Terbiye Dairesi'nce ilk kabul edilen kitaplardan biridir. Osmanlı tarihiyle ilgili konuların ağırlıkta olduğu kitapta, Yakınçağ'da dünya ve Türkiye tarihi Cumhuriyet'in ilanına kadar ele alınmaktaydı. Genel tarihle ilgili konular "Avrupa'nın müstemleke siyaseti"yle sona ermekteydi. Kitapta metin aralarına muhtelif resim ve haritalar yerleştirilmişti.

1923 'ten sonra Ahmet Refik (Altınay), Ali Reşat, Hamit (Ongunsu) ve Muhsin (Teker) lise ve ortaokullara yönelik ders kitapları yazdılar. HamitMuhsin imzasıyla ortaokul üçüncü sınıflar için yazılan Türkiye Tarihi, 1930 yılında bazı küçük değişikliklerle üçüncü baskısını yaptı. Osmanlı tarihiyle ilgili konuların ağırlıkta olduğu bu kitapta resimlere, dipnotlara ve bölüm sonlarında okuma parçalarına yer verilmişti ${ }^{19}$.

Cumhuriyet'in ilk yıllarında, Tarih ders kitaplarının muhteviyatında önemli değişiklikler yapılmakla birlikte geçmişten gelen alışkanlıklar ve bakış açısı tamamen silinmemiştir. İşte bütün bunlar, bazı tarihçilerin ciddi eleştirilerine sebep olacaktır. Yusuf Akçura bu eleştirileri yapanların başında gelmektedir.

Yusuf Akçura, öncelikle ders kitaplarında hakim olan skolastik anlayışın terkedilmesi gereğini savunmaktaydı. Mayıs 1925'te İstanbul Erkek Muallim Mektebi'nde verdiği bir konferansta bu konuya değinerek, okullarımızda okutulan "tarih-i hususî" kitaplarının çoğunluğu, "tarih-i umumî" kitaplarının ise hemen hepsinin skolastik anlayıșa göre yazıldı ğını ileri sürüyordu. Tarih kitabı yazarlarımız, tarihî olayları sadece Fransızların gözüyle bakmaktaydılar. Herhangi bir yazarın Eskiçağ, Ortaçağ veya Yakınçağ'a ait bir kitabına bakıldığında bu görülecektir: "Bunların cümlesi, yek nazarda tercüme edilmiş Fransız kitapları tesirini verir. Müellif ancak, Fransız kelimelerin mukabilini bulmak için zihnini işletmiş zannedersiniz. Tarihe bakılan zaviye-i rüeyyet Türkiye'de değil, Fransa'da vakidir.". Akçura, Osmanlı Tarihi için de aynı tesbitte bulunarak, "Hoca Sadettin hangi şemayı kabul etmişse, hemen ona bağlı kalmışızdır. Böylece tarihi teliflerimiz, ecnebilerin veya vaziyetin sultalarına mağlup ve mahkum bir haldedir; yani skolastiktir. ${ }^{20}$ demektedir.

${ }^{18}$ İhsan Şerif, Cumhuriyet Çocuklarına Tarih Dersleri, İkdam Matbaası, İstanbul 1926. Yazar, daha önce yayınladığı benzer bir kitapta Sultan İkinci Abdülhamid ile Sultan Reşad'a yer vermemiş; Sultan Vahdettin'den övgüyle bahsetmiştir. Bkz., İhsan Şerif, Çocuklara Tarih-i Osmani, Kanaat Matbaası, Dersaadet 1338.

${ }_{19}$ Mustafa Safran, "Osmanlı Tarihi Öğretimi ve Osmanlı İmajı", Türk Yurdu, Sayı:148-149, (Aralık 1999-Ocak 2000), s.488; Büşra Ersanlı Behar, İktidar ve Tarih, İstanbul 1992, s.99.

${ }^{20}$ Yusuf Akçura, "Skolastik Zihniyeti Tard ve Def'etmeliyiz", Maarif Vekaleti Mecmuası, Sayı:3, (1 Temmuz 1341), Ankara, s.63. 
Yusuf Akçura, bu konudaki tenkitlerini Birinci Türk Tarih Kongresi'nde de dile getirmiştir. Türkiye Cumhuriyeti'nin kuruluşundan sonra tarih programları değiştirilmiş ise de, o programlara uygun tarih kitapları hemen hazırlanıp yayınlanamadı̆̆ından, Osmanlı döneminden kalan kitaplar tamamen kaldırılamamıştı. Ancak geçen süre içerisinde yeni bazı kitaplar yazılabildi. Eski kitaplar milliyet, halkçılık esaslarına göre tekrar gözden geçirildi ise de, "yapılan tadiller ve 1slahlar asıldan ziyade şekle, ruhtan ziyade maddeye ait idi". Akçura, Ali Reşat Bey'in lise üçüncü sınıflar için yazdığı "Tarih-i Umumî"sini buna örnek olarak gösteriyordu.

Söz konusu kitap 1929 yılında Maarif Vekaleti'nce yayınlanmıştı. Ali Reşat Bey, "Meşrutiyet devrinde yazdığı kitapları biraz tadil ile vücuda getirdiği" bu kitapta, daha önceki yazdıklarından kolayca yararlanabilmek için yürürlükteki müfredat programının dışına çıkmak zorunda kalmıştı. Böylece, Meşrutiyet dönemindeki hatalar Cumhuriyet döneminde de tekrarlanmıştı. Bu eser millî bir tarih görüşünden ziyade, Fransız tarihçilerinin bakış açısını yansıtmaktaydı. II. Meşrutiyet döneminde umumî tarih, "Avrupa müverrihlerince kabul edilmiş olan çerçeve içine tamamen yerleşmişti." Bu dönemde, "Ali Reşat Bey ve diğer tarih-i umumî telif eden meslekdaşlarımız, Fransız tarih-i umumî kitaplarını pek cüzi tadillerle aynen tercüme etmişlerdi". Bunun sonucunda resmi ders kitaplarımıza, Fransız tarihçilerinin belirli gayeler doğrultusunda hazırladıkları tarih kitaplarındaki bakış açısı hakim olmuştu.

Ali Reşat Bey'in, İslamiyet öncesi Türk tarihi hakkında verdiği bilgiler yanlış ve yetersizdi. Üçyüz otuz altı sayfalık kitabın sadece 24 sayfası bu konuya ayrılmıştı. Türk tarihinin başlangıcı ve Türk medeniyeti hakkında hiçbir bilgi vermeyen yazar, Orhun abidelerinden de gereğince bahsetmemişti. Türk tarihinin bu dönemini Leon Kahün'den yararlanarak yazarken "müsbet vakıalardan ziyade efsaneler ve hikayelerle meşgul olmuştur".

Kitapta, İslam tarihi ve Türklerin İslam dünyasındaki rolü hakkında da bir çok yanlışlıklar görülmekteydi. Bir çok yazarlarımız gibi, Ali Reşat Bey de İslam medeniyetini Arap medeniyeti şeklinde gösteriyordu. Akçura'ya göre, "İslam devrinde Türk devletlerinin ve Türklerin medeniyete hizmetleri de tebarüz ettirilmemiş ve müfredat programı bu gayeyi takip ettiği halde müellif, membalarından ayrılmamak için, programdan inhiraf eylemiştir." Ali Reşat Bey, kitabında Yakınçağ tarihini müfredat programını dikkate almayarak, "adeta bir Fransız asr-1 hâzır tarihi" gibi yazmıștır. Akçura'nın ifadesiyle, "Bu kısım yazılırken müellif Türklüğünü unutmuş gibidir."21

Bütün bu eleştiri ve yaklaşımlar, 1930 yılından sonra yeni bir tarih görüşünün uygulanmasına zemin hazırlamıştır. Önce Türk Ocakları Türk

${ }^{21}$ Yusuf Akçura, "Tarih Yazmak ve Tarih Okutmak Usullerine Dair”, Birinci Türk Tarih Kongresi, (Konferanslar, Müzakere Zabitları), Maarif Vekaleti, (t.y), s.597-602. 
Tarihi Tedkik Heyeti, daha sonra da Türk Tarihi Tedkik Cemiyeti (Türk Tarih Kurumu) bu konuda öncülük yaptılar. Bu dönemde kesin olarak belirlenen Türk Tarih Tezi de ders kitaplarına girmeye başladı.

İlk olarak Türk Ocakları Türk Tarihi Tetkik Heyeti tarafından 1930'da, Türk Tarihinin Ana Hatları adlı hacimli bir kitap hazırlandı. Sınırlı sayıda basılan bu kitap, tarihçilere dağıtılıp görüşleri alındı. Kitabın önsözünde, "Şimdiye kadar memleketimizde neşrolunan tarih kitaplarının çoğunda ve onlara mehaz olan Fransızca tarih kitaplarında Türklerin dünya tarihindeki rolleri şuurlu ve şuursuz olarak küçültülmüştür. Türklerin ecdat hakkında böyle yanlış malumat alması, Türklügüü kendini tanımasında, benliğini inkişaf ettirmesinde zararlı olmuştur." deniliyordu. Bu sözler, Yusuf Akçura'nın daha önce söz konusu ettiğimiz görüşleriyle büyük benzerlik göstermektedir. Türk tarihiyle ilgili yanlışların düzeltilmesi ve bu alanda çalışacaklara genel bir istikamet ve hedef göstermeyi amaçlayan bu eser, "son büyük hadiselerle ruhunda benlik ve birlik duygusu uyanan Türk milleti için millî bir tarih yazmak ihtiyacı önünde atılmış ilk adım"1 oluşturmaktaydı. Kitabın giriş kısmı 1931'den itibaren üç ayrı basımda 70 bin adet basılarak dağıtıldı. ${ }^{22}$ Böylece kamuoyunun yeni tarih tezinden haberdar olmasına çalışıldı.

15 Nisan 1931'de Atatürk'ün himayesinde kurulan Türk Tarihi Tedkik Cemiyeti, okul kitaplarının yeniden yazdırılmasına öncülük etti: Liseler için dört ciltlik bir tarih serisi hazırlandı. "Mihverini Türk tarihi teşkil eden ve hafriyatlardan çıkarılmış vesikalarla ana kaynaklardan alınmış müsbet malumata istinat eyleyen" bu kitaplar, 1931-1932 öğretim yılından itibaren liselerde okutulmaya başlandi ${ }^{23}$. Maarif Vekaleti, daha sonra bu kitapları esas alarak ilk ve ortaokullar için yeni tarih kitapları hazırlattı.

Bu kitaplar baskı, cilt, resim, harita ve içerik itibarıyla öncekilere göre oldukça farklıydı. Bu aynı zamanda, Atatürk'ün Türk tarihinin öğretimine verdiği önemi göstermektedir. Maarif Müsteşarı Salih Zeki Bey, "Tarih ve yurt bilgisi tedrisatı(nın) en mütekamil bir şekilde" yapılacağını belirterek bu derslerle ilgili kitapların, "Avrupa müessesatında takip edilmekte olan

${ }^{22}$ Etienne Copeaux, Türk Tarih Tezinden Türk-İslam Sentezine, İstanbul 1998, s.3940; İkinci Türk Tarih Kongresi, (İstanbul 20-25 Eylül 1937), Kenan Matbaası, İstanbul 1943. s.II-VI.

${ }^{23}$ Cumhuriyet Halk Partisi On Beşinci Y1l Kitab1, s.570; Copeaux, a.g.e., s.40-41; Behar, a.g.e., s.108,112-116. 1931-1932 öğretim yılı yaklaştığında, Maarif Vekaletince hazırlanan tarih kitaplarıyla yurt bilgilerinin Devlet Matbaasında baskıları henüz tamamlanamamıştı. Maarif Vekaleti Yayın Müdürü Faik Reşit Bey, Eylül ayının sonuna kadar bitirilmesi kararlaştırılan kitapların İstanbul'da baskı işlerini takip ediyordu. Kitaplar hazırlanıncaya kadar öğretmenler, derslerini müzakere ve tekrar şeklinde idare edeceklerdi., bkz., "Yeni Tarih Kitapları", Cumhuriyet, 26 Eylül 1931. 
kitaplardan daha mükemmel ve daha nefis bir şekilde hazırlanmıştır." ${ }^{24}$ diyordu.

Liseler için hazırlanan kitapların dördüncü cildi Milli Mücadele, Cumhuriyet'in kuruluşu ve inkılâpları kapsamaktaydı. Bir çok resim ve haritayı içeren kitap oldukça kaliteli bir kağıda basılmıştı ${ }^{25}$.

Lise kitaplarının yayınlanmasından önce, ortaokullarda okutulmak üzere dört ciltlik resimli ve haritalı bir umumî tarih hazırlanarak yayınlanmışt ${ }^{26}$. Daha sonra dört ciltlik lise kitapları sadeleştirilerek önce ortaokullar, sonra da ilkokullar için kitaplar yayınlandı. Ortaokullar için hazırlanan üç ciltlik kitabın ilk cildi Ortamektep İçin Tarih adıyla 1933'te yayınlandı. Bu kitaplarda Türk Tarih Tezi belirgin bir şekilde yansitiliyordu ${ }^{27}$.

Yine ortaokul üçüncü sınıflar için, 1934 yılında Talim ve Terbiye Heyeti tarafından kabul edilen başka bir kitap yayınlandığı görülmektedir. Sadri Ertem ve Kazım Nami Duru tarafından hazırlanan bu kitap ${ }^{28}$ Osmanlı İmparatorluğu'nun kuruluşuyla başlıyordu. Osmanlı tarihi Avrupa'daki gelişmelere paralel olarak Birinci Dünya Savaşı'nın sonuna kadar getirilmekteydi. Kitabın yarısına yakın kısmı Atatürk, İstiklal Harbi, Cumhuriyetin kuruluşundan sonraki gelişmeler ve inkılâplara ayrılmıştı. Sayfa aralarında konularla ilgili resimlere yer verilen kitabın sonuna Osmanlı imparatorluğu, Avrupa ve Türkiye Cumhuriyetiyle ilgili sekiz harita eklenmişti.

24 “Muallimlerin Maaşı”, Cumhuriyet, 16 Eylül 1931.

${ }^{25}$ Behar, a.g.e., s. 114-116. Bu cildin ilk konusu olan Türkiye Cumhuriyeti'nin Kuruluşu'na girişte şunlara yer verilmekteydi: "Beşer tarihinde, Türkler kadar ve çok ve büyük devletler kuran bir ırk gelmemiştir. Tarihçe malum ilk medeni devletten beri (Sumer Devleti, M.E. 4000 yil) Asya'da ve Avrupa'da tesis edilen beyliklerin (prensliklerin), hanlıkların (krallıkların), hakanlıkların (imparatorlukların) çoğunu Türkler kurdu. Bir Türk devleti tarihe karıştı mı, derhal başka bir veya birkaç Türk devleti hayat sahnesine çıkar. Büyük Harp sonunda (1918), Osmanlı İmparatorluğu yıkılıp parçalanırken, Türk kudreti yeni bir devlet daha meydana getirdi. Bu yeni devlet, tam muasır bir tarzda kurulan "Türkiye Cumhuriyeti"dir.", bkz, Tarih IV, Türkiye Cumhuriyeti, İstanbul 1931, s.1.

${ }^{26}$ Akçura, a.g.m., s.597.

${ }^{27}$ Behar, a.g.e., s.111; "Ortamektep İçin Tarih'in üç cildinden çıkan genel anlayış şudur: Osmanlı ve Cumhuriyet devletlerini de içeren Türk devletçiğinin zaferi, kuvvetli bir ırkın, kuvvetli bir dilin ve çok çok eskilere dayanan devlet kurma geleneğine dayanmaktadır. Irki özellikler diğer imparatorluklanı ve hanedanları, yani Çinlileri, Mısırlıları, Hintlileri, İranlıları ve Yunanlıları geride bırakmaktadır. Türk devletçiliğinden ne anlaşıldığı bu kitaplarda açık bir şekilde görülmemektedir. Eski şehir devleti anlaşılamayacağına göre, tarih öncesi ve tarihin ilk çağlarında modern devlet teorisi de varolmadığına göre, devlet anlayışı hayli muğlaktır. Bu devlet tarih öncesi ve tarihi çağlardaki siyaset teorisi kavramlarından herhangi biriyle açıklanamaz. Devlet ırk ve dil dayanışmasıyla kurulan bir kültürel otorite olarak algılanmaktadır. Bu dayanışmanın siyasal ve idari sınırları belirsizdir.", bkz., Behar, s.111. E. Copeaux ilk cildin 1934 yılında basıldığını yazıyor, a.g.e., s.41, dipnot 90 .

${ }^{28}$ Sadri Ertem- Kazım Nami Duru, Ortaokul İçin Tarih III, Ankara 1941. 
1936 yılından itibaren Tarih müfredatının yoğunluğu tartışılmaya başlanmıştır. Bu doğrultuda bazı düzenlemeler yapılmış olmakla birlikte, çok müsbet bir sonuca varılamamıştır. Ortaokul ve liselerde okutulan tarih kitaplarında, 1936 yılında "fevkalade bir değişiklik" yapılmamıştı. Ancak, ilkokulların dördüncü ve beşinci sınıflarında okutulan tarih kitaplarına, " Türk Tarihi Tedkik Cemiyetinin, son tarihi araştırmalarından alınan neticelere göre, tekemmül eden tezlerinden" bazı parçalar ilave edilmişti ${ }^{29}$.

Maarif Vekaleti 1937 yılında ortaokul ve lise tarih kitaplarını yeniden düzenlemek üzere, Ankara'da bir komisyon oluşturdu. Komisyona, İstanbul'dan Yüksek Muallim Mektebi Müdürü Hamit Bey de çağrılmıştı. Hazırlanacak yedi ciltlik kitaplardan üçü ortaokullar, dördü ise liselere yönelik olacaktı. Maarif Vekaleti, "sırf bir usul meselesinden" kaynaklanan bu girişimin gerekçesini, " Malûm olduğu üzere şimdiye kadar, gerek mektepler için, gerekse sırf bir tedkik mahsulü olarak yazılan bütün tarih kitapları bir kronolojiden ibarettir. Bunlar ya şahısların terceme-i hallerinden yahut da bir harb ve istiladan ibaret oldukları için muhayyileyi hiç işletmemekte ve talebeyi ezberciliğe mecbur etmektedir. Halbuki en modern tarih tedrisatı usullerine göre talebeye böyle kronolojileri ve günü gününe vakaları öğretmektense bu vakayı icab ettiren tarihî, ictimâ̂, iktisadî sebepleri araştırmak ve ancak bu araştırma dolayısıyla vakaya ve terceme-i hallere temas etmenin doğru olabileceği anlaşılmaktadır." 30 şeklinde açıklıyordu.

\section{Tarih Öğretimi}

Müfredat programları ve ders kitaplarını yenileştirme çabalarının yanı sıra tarih öğretimiyle ilgili yeni arayışlar içine girilmiştir. Programlarda çoğu kez öğretim metotlarıyla ilgili tavsiyelere yer verilmiştir. Aynı zamanda tarih, iyi bir yurttaşlık eğitiminin vazgeçilmez unsuru olarak görülmüştür.

1926 tarihli ilkokul müfredat programında, tarih öğretiminde dikkat edilecek noktalar sıralanırken, başta öğretimin asıl odağının Türk Tarihi olduğu vurgulanıyordu. İlkokullarda Genel tarih okutmaya öğrenci seviyesi ve zaman müsait olmadığından, Genel tarihin önemli kısımları Türk tarihiyle bağlantı kurulmak suretiyle ögretilecekti. Hükümdarların hayatları ve savaşlardan ziyade medeniyet tarihine önem verilecekti. Dersin daha somut bir hale getirilmesi için okulda kara tahta, harita, tarihî levhalar, kartpostallar ve tarihî okuma parçalarından yararlanılması; ayrıca, okul dışında müze, kale, kule ve su kemerleri gibi tarihi eserlerin tanıtılması öneriliyordu ${ }^{31}$.

29 "Orta Mektep Tarih Kitaplarına İlaveler Yapıldı", Cumhuriyet, 9 Teşrinievvel 1936; Enver Ziya Karal, “Tarih Öğretimi ve Meseleleri”, Eğitim Hareketleri, Sayı:23, (1956), s.16.

30 "Tarih Tedrisatında Değişiklik Yapılıyor", Cumhuriyet, 27 Mart 1937.

${ }^{31}$ İlk Mekteplerin Müfredat Programı, 1927, s.71-72. "Öğretmen dersi isimlere ve tarihlere boğmayacak, okunması ve bellenmesi zor isimleri ders esnasında tahtaya yazacaktır. Tarih dersinin coğrafya dersiyle paralel gitmesine dikkat edilecektir. Ders esnasında haritadan 
Harita, eskiden beri tarih öğretiminin vazgeçilmez materyallerinden biri olarak görülmüş̧ür. Mekteb-i Sultani müfredat programında, "Her sınıfta hadisat-1 tarihiye behemehal tarihi haritalar üzerinde takip edilecektir. Tarihî harita bulunmadığı takdirde, bu hususta coğrafya haritalarından istifade olunacaktır" $^{132}$ deniliyordu. 1928 yılında Köprülüzade Mehmet Fuat (Fuat Köprülü) ve Faik Sabri (Unat) tarafından müștereken bir kısmı ilkokullara, diğer kısmı da ortaokul ve lise öğretmenlerine yönelik olmak üzere bir Tarihi Atlas hazırlanmışt1 ${ }^{33}$.

Bu yıllarda ilkokullarda tarih öğretiminin sonuçlarını anlamaya yönelik anketler de yapılmıştır. İstanbul Erkek Muallim Mektebi Tatbikat Mektebi öğretmeni Ali Fahrettin (Alper), 27 Mayıs 1925 'te iki ilkokulun üç sınıfında $(3,4,5)$ tarih okuyan 150 öğrenci arasında yaptığı anket sonuçlarını yayınlamışıır ${ }^{34}$. Bunun, o dönem için eğitimin sonuçlarını anlamaya yönelik nadir çalışmalardan biri olduğu söylenebilir.

İlkokullarda olduğu gibi, ortaokul ve liselerde de iyi bir tarih öğretimi için arayışlar sürmüştür. Maarif Vekili Mustafa Necati Bey, 1927-1928 öğretim yılı başında, "lise tedrisatında takibi lazım gelen usul hakkında" öğretmenlere hitaben 22.9.1927 tarihinde yayınladığı tamimde, "Türkçe, edebiyat ve tarih tedrisat 1 gençlerde azami tarzda mütalaa zevkini uyandırmalıdır. Lise talebesini iyi neşriyatla alakadar etmeli ve onlara okumak iştiyakını vermelidir. Bunun için muallim, gençlerin seviyesiyle mütenasib eserler hakkında bunların merak ve alakalarını davet eyleyecek tedabirler almalı ve imkan mertebesinde bu eserleri derslerine rabt edebilmeli ve onları okumaya, onlardan hülasa yapmaya, o eserler üzerinde tahliler ve tenkidler hazırlamaya davet eylemelidir" ${ }^{35}$ diyordu..

Yeni ders kitaplarının hazırlanıp okutulmaya başlanmasından sonra, 1933'te, Darülfünûn (Üniversite) müderrislerinden Hamit Bey, Maarif

yararlanılacak; eğer okulda istenilen harita yoksa, öğretmen kendisi renkli tebeşirle siyah tahtaya krokiler çizecektir. Ders esnasında tarihi levhalar da gösterilecektir. Eğer levha yoksa, öğretmen kitaplardan tedarik edebildiği levhaları ve kartpostalları gösterir. Okulda tarihi kartlardan oluşacak bir kolleksiyon yapılması tavsiye olunur. Öğretmen öğrencilere müze ve eski eserleri gösterecektir. Müze olmayan yerlerde öğretmen kale, kule, su kemerleri gibi eski eserleri gösterir ve tarihi hakkında bilgi verir. Tarih derslerinde çocuklara verilen bilgiler, tarihi okuma parçalarıyla desteklenmelidir.". Yine öğretmen 4. sınıf öğrencilerine Beşeriyetin Illk Zamanlarını anlatırken, "dersten evvel hazırlanacak resimlerle ve kıraat parçalarıyla canlandırılacak ve bugün göçebe ve aşiret halinde yaşayan insanlarla medeni milletler mukayese edilecektir.", a.g.e., s.72.

${ }^{32}$ Mekatib-i Sultaniye Müfredat Programı, Matbaa-i Amire, İstanbul 1338, s. 213.

${ }^{33}$ Mehmed Fuad, Millî Tarih, 1928, s. 169.

${ }^{34}$ Ali Fahreddin, "Ilk Mekteplerde Tarih Tedrisatı", Tedrisat Mecmuası, C.XIII, No:67, (Mayıs 1925), s. 317-338. Bu metnin Bahri Ata ve Şeyma Şahan tarafından günümüz alfabesine çevirisi için bkz., Ali Fahreddin (Alper), "Illk Mekteplerde Tarih Tedrisatı", Türk Yurdu, C.XXII, Sayı:175, (Mart 2002), s.91-99.

${ }^{35}$ Maarif Vekaleti Mecmuası, Say1:15, (Nisan 1928), İstanbul, s.503. 
Vekaleti'nce ortaokul ve liselerde Türk tarihi öğretiminin teftişiyle görevlendirildi. Hamit Bey, daha önce İstanbul'daki öğretmenlerden, tarih derslerini müfredat programına göre yeni esaslar dahilinde nasıl yaptıklarına dair bilgi toplamıştı. Bu raporların ışığında, tarih öğretimini daha iyi bir düzeye çıkarabilmek için lise ve ortaokul öğretmenleriyle bir toplantı yapmıştı ${ }^{36}$. Tarih öğretiminde ders kitaplarının önemi gözönüne alınarak, 1937 yılında, öğrencileri ezberciliğe sevkeden kronolojik bilgilerin azaltılarak, araştırma ve anlamayı teşvik eden konulara ağırlık verilmesi için teşebbüse geçildi.

Tarih öğretiminin gayesi ve hedefleri ne olmalıdır, sorusunu dönemin eğitimcileri cevaplamaya çalıșmışlardır. Kazım Nami (Duru), "işin en mühim ciheti gerek millî, gerek umumî tarihin nasıl bir gaye için tedris edileceğini tayin etmektir" diyerek dikkatleri bu konuya çekmektedir. Kazım Nami, başta Millî tarihin önemini takdir etmekle birlikte, bunu insanlık tarihinden ayrı düşünmemektedir. O, " Türkiye asırlarca müddet kasr ve tazyik edilmiş bir vicdanın halasa tezahürü önünde biraz inhisarcı bir milliyetçilik takip etmektedir. Bundan tabii bir șey olamaz. Ben Türküm yani, Türk denilen en eski şerefli en cevahirli bir millete mensubum" demektedir. Bununla birlikte Genel tarih eğitiminin gereğine olan inancını "Fakat benim bu tarihim ve bu hamlem; insaniyetten ayrı mücerred bir şey değil. Ben de arzda yaşayan ve arzı yaşatan tek varlığın; insanlığın bir cüzü, bir uzvuyum. Tarih benim oğluma bu bilgiyi vermeli; tarih benim oğluma bu duyguyu aşılamalı" sözleriyle açıklayan Kazım Nami'ye göre, "Tarih; demokrat cumhuriyetçi bir milletin müstakbel nesli için en iyi bir insanî ve millî terbiye aletidir.".137

1930'dan sonra okullarda Türk tarihine daha da önem verildiği bilinmektedir. Ortaokul üçüncü sınıflarda okutulan bir tarih kitabında, tarih ve yurtbilgisi derslerinin millîleştirilmesi anlatılırken, "Tarih geçmişimizin bir aynasıdır. Oraya bakınca, Türk milletinin binlerce yıldan beri nasıl yaşamış, neler yapmış, medeniyete, insanlığa ne büyük hizmetler etmiş olduğunuzu anlarsınız. Her millet, kendi tarihine çok değer verir. Fakat tarihler içinde en eskisi, en şereflisi ve şanlısı Türk tarihidir" ${ }^{18}$ denilmektedir. Ancak bu kıyaslamalar dışında, ders kitaplarında hiç bir zaman diğer milletlere karşı düşmanlık ifadelerine yer verilmemişti.

1930'larda Millî Eğitim teşkilatının başında bulunanlar da benzer görüşleri savunuyorlardı. Talim ve Terbiye Dairesi Başkanı İhsan (Sungu), Maarif Vekaleti'nde müsteşar Mehmet Emin (Erişirgil) ve Talim ve Terbiye Dairesi üyesi Avni (Başman) Beyler, okullardaki hürriyet ve tarih öğretimi hakkında düşüncelerini belirtirlerken, öncelikle ilkokullarda tarih öğretiminin millî hisleri geliştirmeye yönelik olması gereğini

\footnotetext{
36 "Mekteplerde Tarih Tedrisatı", Cumhuriyet, 5 Mayıs 1933.

${ }^{37}$ Kazım Nami, "Tarih Tedrisatı Hakkında", Fikirler, Sayı:25, İzmir, s.6-7.

${ }^{38}$ Sadri Ertem- Kazım Nami Duru, a.g.e., s.270-271.
} 
vurguluyorlardı. Tarih ortaokul ve liselerde daha geniş olarak öğretilebilirdi. Türkiye'de tarih öğretiminin milliyetçi, fakat emperyalist olmadığ 1 görüşündeydiler. Öğretmen Okulu Müdürü Sadrettin Celal (Antel) ve öğretmenlerden Hıfzırrahman (Öymen) Bey, doğru ve tarafsız tarih öğretimini savunuyorlardı. Her milletin kendi tarihini öğretirken bu ilkeye uyması, insanlık için çok iyi bir kazanç olur; ülkeler arasında barışı gerçekleştirebilirdi ${ }^{39}$.

1930'lardan sonra Türk Tarih Tezi doğrultusunda hazırlanan kitaplarda diğer milletlere karşı aşağılayıcı herhangi bir ifadeye yer verilmemişti. Ocak 1932 'de Paris'te toplanan Uluslararası Tarih Tedrisatı Kongresine Türk Tarihi Tedkik Cemiyeti'ni temsilen katılan Genel Sekreter Muzaffer Göker, "Kurumun liseler için yazdığı tarih kitaplarının milletleri birbiri aleyhine tahrik eden düşmanca fikir ve mevzuları ihtiva etmediği"ni belirterek, diğer ülkelerin okul kitaplarındaki bu gibi cümlelerin çıkarılmasını temenni etmişti ${ }^{40}$. Enver Ziya Karal da bu konudaki görüşlerini, "Bundan başka bugün Türk Tarih kitaplarında herhangi bir milleti küçültücü, incitici bilgiler de yoktur. Bütün bu hususlar dikkate alınınca; Türk Tezi'nin ve tarih öğretiminin milli ülkü ile insanlık ülküsünü ayıran bir tarafı bulunmadığı, aksine, bu iki ülküyü müstakil karakterlerini muhafaza etmek suretiyle bağdaştırmağa çalıştığı görülmektedir." ${ }^{41}$ sözleriyle ifade etmektedir.

\section{Sonuç}

Türkiye'de tarih öğretiminde özellikle II. Meşrutiyet döneminden itibaren başlayan arayışlar, Cumhuriyet'in ilk yıllarında daha belirli bir çizgide devam etmiştir. 1924 ve 1926 tarihli ilkokul müfredat programları Cumhuriyet'in beklentilerine uygun değişikliklerin ilk işaretlerini vermektedir. Özellikle 1926 ve daha sonra yapılan değişikliklerle, çocuklara genel tarih kültürünün yanı sıra millî tarihin öğretilmesi hedeflenmiştir. Genel tarih anlayışı, İslam tarihi sınırlarını aşarak insanlığın geçmişini kapsayacak şekilde genişletilmiştir. Millî tarih öğretiminde ise, daha köklü değişiklikler yapılmıştır: Türk tarihi başlangıçtan itibaren bir bütün olarak ele alınmış, İslam tarihi içinde Osmanlı tarihi öncesine geniş yer verilmiştir. Öncekilerden farklı olarak programda İslam tarihine hiç yer verilmemiş, Osmanlı tarihi de hanedana övgü olmaktan çıkarılmıştır.

Cumhuriyet'e intikal eden müfredat programında, sultani (lise)lerin ilk devresinde "Tarih-i Enbiya, Tarih-i İslam"ın yanı sıra Osmanlı tarihi, Avrupa tarihi ve Genel tarih konularına yer veriliyordu. Liselerin ikinci devresinde ise Osmanlı tarihinin yanı sıra Avrupa tarihi okutulmaktaydı. Ayrıca, Fen şubelerinden farklı olarak Edebiyat şubelerinde okutulan dört saatlik tarih dersinde Genel tarih konuları ve İslam ve Türk medeniyet tarihi

${ }^{39}$ Carleton Waşbürne, "Batı Tesirindeki Türkiye Maarifi”, (Çev. Müşerref Dede), Eğitim Hareketleri, Sayı:35, s.18-21.

${ }^{40}$ Cumhuriyet Halk Partisinin On Beşinci Yılı, s.575.

${ }^{41}$ Karal, a.g.m., s. 17. 
hakkında bilgiler veriliyordu. 1924'te yapılan program değişikliği temelde çok önemli bir değişiklik getirmemişti. Avrupa merkezli bir tarih ögretiminin benimsendiği bu programda, Genel tarih ve Avrupa tarihine Türk tarihinden daha fazla yer ayrılmıștı. Bu programın öncekinden en önemli farkı, İslam tarih ve medeniyetine yer verilmemesidir. Buna karşıllık programa, 1926 ilkokul programında da yer alacak olan, çağdaş dünyayı ve Türk dünyasını tanımaya yönelik yeni konular ilave edilmiştir.

$\mathrm{Bu}$ yıllarda müfredatlara bağlı olarak yeni ders kitapları hazırlanmış, özellikle ilkokul ders kitapları millî tarih anlayışı çerçevesinde yazılmaya başlanmıştır. Bu değişiklik ders kitaplarının adında açık bir şekilde görülmektedir. Fuat Köprülü, Milli Mücadele ve Cumhuriyet'in ilk yıllarında ilkokullara yönelik "Millî Tarih" kitapları yazmıştır. Bununla birlikte, ortaögretimde müfredata uygun yeni kitapların hazırlanması pek kolay olmamıștır. Osmanlı döneminden kalan kitaplar tamamen kaldırılmamış, yenilerinde de Meşrutiyet devrindeki hatalar tekrarlanmıştır. Yusuf Akçura, okullarda okutulmakta olan tarih kitaplarının çoğunun, özellikle Genel tarih kitaplarının, skolastik anlayışa göre ve Fransız tarihçilerin bakış açısıyla yazıldığını ileri sürmüştür.

1930'ların başında Türk Tarihi Tedkik Cemiyeti, tarih ders kitaplarının yeniden yazdırılması teşebbüsüne öncülük etti. Liseler için hazırlatılan dört ciltlik ders kitabı, 1931-1932 öğretim yılından itibaren okutulmaya başlandı. Daha sonra, bu kitaplar esas alınarak ilk ve ortaokullar için yeni kitaplar hazırlandı. Kitapların, içerik ve şekil itibariyle öncekilerden çok daha mükemmel olması sağlanmıştı. Bu tarihte kesin olarak belirlenen Türk Tarih Tezi yeni ders kitapları vasıtasıyla okullara girmeye başlamıştır. Üniversite ve yüksekokullarda İnkılap Tarihi derslerinin verilmesi de bu yıllarda gerçekleşmiş̧ir.

Tarih müfredatlarında yapılan değişiklikler, programların yoğunluğuna yönelik eleştirileri ortadan kaldırmamıștır. 1936 yılından itibaren bazı düzenlemeler yapılmakla birlikte, istenilen neticeye ulaşıldığını söylemek güçtür. Liselerin Fen ve Edebiyat şubelerinde okutulmakta olan tarih dersleri 1936'da eşit duruma getirilmesi, bu çerçevede yapılan değişikliklerden biridir. Ayrıca, programların uygulanmasında geleneksel öğretim metotlarının yanı sıra yeni arayışlara yönelindiği dikkati çekmektedir.

Cumhuriyet'in ilk yıllarında, özellikle 1930'lardan sonra tarih, iyi bir yurttaşlık eğitiminin temel unsurlarından biri olarak kabul edilmiştir. Millî tarih öğretimine öncelik verilmekle birlikte, bunun insanlık tarihinden ayrı düşünülemeyeceği vurgulanmıştır. Millî Eğitim teşkilatında etkili olan eğitimciler, ülkeler arasında barışın sağlanmasında doğru ve tarafsız bir tarih eğitiminin önemini savunmuşlardır. Milli bir özelliğe sahip olan Türk Tarih Tezi ve tarih öğretimi, diğer milletlere düşmanlık besleyen bir vasita haline getirilmemiştir. Tarih ders kitaplarında diğer milletleri aşağılayıcı herhangi bir ifadeye yer verilmemesi, uluslar arası kongrelerde bir övünç kaynağ 1 olarak sunulmuştur. 